\title{
Oil Spill Biodegradation by Bacteria Isolated from Jakarta Bay Marine Sediments
}

\author{
Angga Dwinovantyo, Santi Susanti, Nico Wantona Prabowo, Restya Rahmaniar, Tri Prartono* \\ Department of Marine Science and Technology Faculty of Fisheries and Marine Sciences \\ Bogor Agricultural University \\ Jl. Agatis, Kampus IPB Dramaga Bogor 16680 Indonesia \\ Email: tripr@ipb.ac.id
}

\begin{abstract}
A laboratory study was conducted with the aim to isolate and identify bacteria from sea sediment and test their biodegradation ability in two place where contaminated with oil spill. Five sediment samples were dissolved by using sterile sea water, and then bacteria isolated with total plate count (TPC) method. Isolated bacteria were cultivated, and adapted using the nutrient conditioned sea water medium. Biodegradation process was done by mixing the bacteria with crude oil and shaken for few days. The number of isolated bacteria varied from $2 \times 10^{2} \mathrm{CFU} \mathrm{ml-1}^{-1} 6$

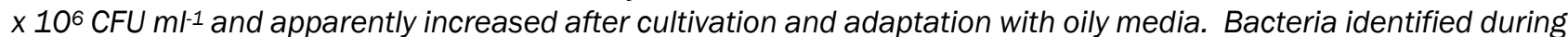
this study were Fundibacter sp., Alcanivorax sp., and Marinobacter sp.. The result of biodegradation process was statistically analyzed and obtained that the bacteria were effective in degrading oil in seven days with constant of biodegradation rate was 0.1766 . GC-MS analysis was conducted to prove the decomposition of carbon chain by bacteria and revealed oil degradation in carbon number 11 to 27 . Based on all analysis, marine sediment bacteria can degrade the oil spill.
\end{abstract}

Keywords : Bacteria, Biodegradation, GC-MS, Marine Sediments, Oil spill.

\section{Introduction}

Oil spill has been known to cause acute and long term damage to marine environment. Oil spill in the ocean derived from broken oil pipe, human activity, and tanker accident. Oil spill generally introduced to marine environment which can cover some area in the ocean with a thin coating of oil that can affect the viability of marine life. In general, oil spill in the ocean encounters natural processes weathering such as evaporation, emulsification, dispersion, photooxidation, biodegradation, and sedimentation (US EPA 2014). Due to the accumulation of oil spill is much faster compared to natural recovery process (Nugroho, 2006), some efforts to minimize the damage of oil spill in marine environment is required to reduce the toxic effects of the oil.

Microbial degradation is an eco-friendly process that uses petroleum degrading bacteria with the results that can be used to reduce the effect of oil spill. Bioremediation is relatively inexpensive, efficient, easy to apply, and it does not cause any further impact to marine environment (Thapa et al., 2012). Oil degradation by natural process shows that marine bacteria are able to break and degrade the carbon chain, and the utilization of sea water bacteria has been tested in various environments (Ni'matuzahroh et al., 2006, Darmayati 2009)

Marine sediment bacteria are one of the promising bacteria that can be applied in bioremediation technology. Sediment as a source of bacteria which has a complex habitat and more potential content of bacteria compared with sea water (Rampen et al., 2012). The aims of this study were to isolate and identify bacteria from marine sediment, and to test the biodegradation of aliphatic compound in two different places that contaminated with oil spill. The indicator to monitor the progress of biodegradation were the bacteria population, $\mathrm{pH}$, the loss of weight of oil (in gravimetric), and GC-MS of the residual oil.

\section{Materials and Methods}

\section{Sampling}

Sediment sample was collected from five stations in Muara Angke Harbor. Oil contaminated water samples were collected from different sites, two stations in Muara Angke and two stations in Rawa Saban (Fig. 1). Sediment samples were collected 
using sediment grab and sealed in sterile bottle sample. Hydrocarbon contaminated water samples were collected using van dorn bottle and stored in polyethylene bottle. All samples were kept in a cool box.

\section{Bacteria inoculum source}

Sediment bacteria inoculum method is based on the procedure developed by Ahmed et al. (2014). Sediment was dried in room temperature. One gram of dried sediment sample was put into a sterile test tube, and then homogenized using a vortex shaker. Sediment precipitated until it was separated from the water, in which the bacteria inoculum was extracted for bacteria isolation process.

\section{Bacteria isolation}

In order to isolate hydrocarbon degrading bacteria consortium, the bacteria inoculum was isolated by plating on plate count agar (PCA) medium using total plate count (TPC) method. Bacteria were isolated by inserting $9 \mathrm{ml}$ physiological solution $(\mathrm{NaCl}$ 9\%) into 4 test tubes (Atlas, 2010). One mililiter of the inoculum containing water was pipetted and transferred into dilution tube $10^{-1}$. The diluted sample was then inserted to a medium-contained petri dish. The same treatment was conducted three times until dilution $10^{-3}$. Each mixture was pippeted $(0,1 \mathrm{ml})$ and transferred into four petri dishes containing 10-15 ml PCA media. All of the isolation process was conducted in laminar air flow during 48 hours and $30^{\circ} \mathrm{C}$ temperature to avoid contamination. TPC was determined by colony forming unit $\mathrm{ml}^{-1}\left(\mathrm{CFU} \mathrm{ml} \mathrm{m}^{-1}\right.$ ) after three days of incubation (APHA, 2012). The method of bacteria cultivation was based on the procedure by Okoro (2010). The isolation products in five samples were cultivated periodically in $100 \mathrm{ml}$ solution medium Nutrient broth (NB). The culture was shaken using environmental shaker at $120 \mathrm{rpm}$ for 48 hours at room temperature. The growth of bacteria was shown by the medium turbidity and the bacteria was counted using TPC method.

The method of bacteria adaptation was based on the procedure developed by Razika et al. (2010). The chosen cultivated and isolated culture was adapted periodically every 72 hours in $100 \mathrm{ml}$ nutrient-conditioning sea water. The nutrientconditioning sea water medium was made by dissolving 1.26 gram $\mathrm{MgSO}_{4} \cdot 7 \mathrm{H}_{2} \mathrm{O}, 1$ gram $\mathrm{KCl}, 2.5$ gram $\mathrm{KH}_{2} \mathrm{PO}_{4}$, 3.75 gram $\mathrm{Na}_{2} \mathrm{HPO}_{4}$, and 1.29 gram $\mathrm{NaNO}_{3}$ in 3 liter of sterile sea water. Crude oil (0.1\%) and bacteria suspended solution (10\%) were added to the medium aseptically, shaken at $120 \mathrm{rpm}$ using environmental shaker for 72 hours at room temperature $\left(28 \pm 2^{\circ} \mathrm{C}\right)$. Bacteria population was counted by optical density. The indicator to monitor the bacteria could live in the medium and be used for biodegradation process is when the population was

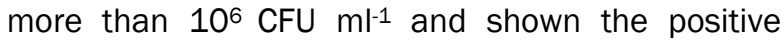
growth after adaptation process (Okoro, 2010).

Identification of isolated bacteria was based on the Biolog Gen III identification system (Biolog Inc., USA). Pure isolates of the adapted bacteria was developed into a nutrient agar (NA) medium. This media was then transferred into a solution of Gram-

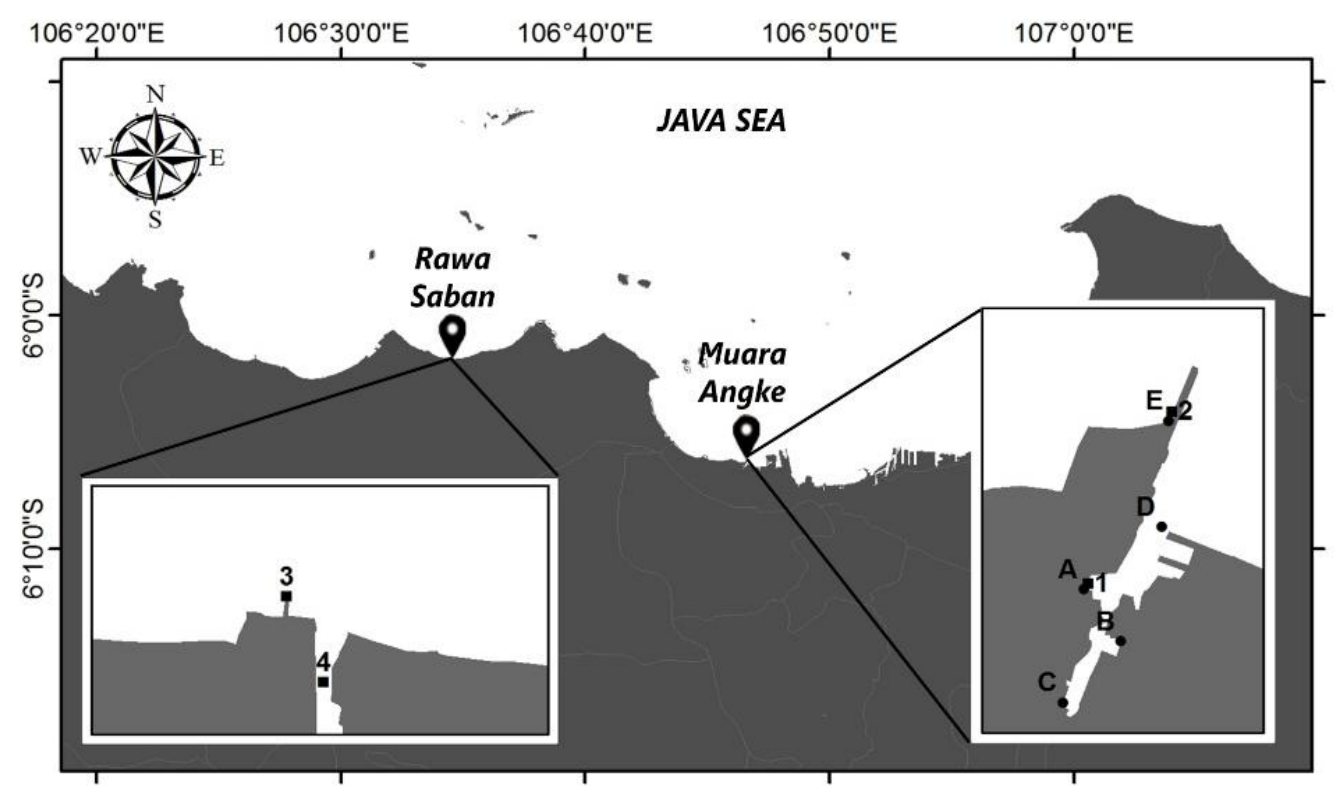

Figure 1. Location map of sediment and water samples in Rawa Saban and Muara Angke Note. $\square$ : Sediment station (A-E), : Contaminated water station (1-4) 
negative bacteria inoculation fluid. This solution was measured by Biolog turbidimeter to indicate bacterial content. Then $150 \mu \mathrm{l}$ of this solution was then pipetted and put into the GN2 MicroPlate ${ }^{\mathrm{TM}}$ and incubated for 16-24 hours. The plate was determined by Micro Station Microplate Reader. The identification process was run by a pre-loaded database ID on a computer. Bacterial species appeared on the monitor in the form of 1-10 species that have an adjacent reaction pattern with the percentage of similarity (Wragg et al., 2014).

\section{Biodegradation test}

The method of bacteria biodegradation analysis followed the procedure developed by AlWasify and Hamed (2014). The $0.5 \mathrm{ml}$ adapted bacteria were inserted into $150 \mathrm{ml}$ oil contaminated water samples in a flask. The solution mixture of bacteria and oil was incubated and shaken at 120 $\mathrm{rpm}$ in room temperature. The early biodegradation observation was conducted by measuring $\mathrm{pH}$ using $\mathrm{pH}$ meter Boeco BT-600. Bacteria growth was measured by spectrophotometer Boeco S-22 UV/Vis using optical density method at $600 \mathrm{~nm}$ (Razika et al., 2010). The bacteria growth can be calculated by the relation of absorbance $=0.7$ equal with $10^{8} \mathrm{CFU} \mathrm{\textrm {ml } ^ { - 1 }}$ (Zheng et al., 2009).

Oil and grease determination in the sample used gravimetric principle which referred to ASTM D4281-95 (ASTM, 2010). Boiling flask that has been dried at $105^{\circ} \mathrm{C}$ in an oven for 1 hour, cooled to room temperature in a desiccator, and weighed. The extraction was begun with added $60 \mathrm{ml} n$-hexane into the sample bottle, and then it was closed and shaken. The mixture was poured into a separatory funnel and extracted by shaking for 10 minutes. Inverted the separatory funnel and vent with stopcock to relieve pressure buildup from $n$-hexane gas during the extraction. The extraction produced two layers which were sea water layer and oil layer bound with $n$ hexane. Oil layer bound with $n$-hexane was put into the boiling flask. To separate the oil and $n$-hexane, $n$ hexane evaporation was done using rotary evaporator with the temperature $70-80^{\circ} \mathrm{C}$. By the end of the evaporation process, there would be oil residue in the boiling flask. After it was cooled, the boiling flask was weighted and noted as boiling flask's oil-contained weight. Oil and grease content was calculated with the formula:

$$
\text { Oil and grease content }\left(\mathrm{mg} \mathrm{l}^{-1}\right)=\frac{B-A}{C} \times 1000
$$

Where $A$ is boiling flask's empty weight (gram), $B$ is boiling flask's oil-contained weight (gram), and $C$ is sample volume (liter). The biodegradation rate can be calculated after all oil and grease calculation have been done, and expressed as:

$$
C_{t}=\mathrm{eC}_{0} \mathrm{e}^{(-k t)}
$$

Where $C_{0}$ is concentration of oil at Day- $0, C_{t}$ is oil concentration in time $\mathrm{t}$, and $\mathrm{k}$ is the biodegradation rate coefficient (Darmayati et al. 2015). The biodegradation rate coefficient uses in this study was depletion (decay) coefficient.

\section{Oil component analysis uUsing GC-MS}

The degraded oil with treatment and crude oil without treatment were analyzed using GC-MS. Before analyzed, the oil was fractionated by column chromatography (3\% deactivated silica; 5 g) and 30 $\mathrm{ml}$ of $n$-hexane to get aliphatic fraction (Prartono and Wolff 1998). Gas chromatography (GC) analysis were performed using an Agilent GC System 7890A equipped with Agilent Inert MSD 5975C detector and HP-5MS (60 m x $0.250 \mathrm{~mm}$; stationary phase 0.25 $\mu \mathrm{m})$ column with helium ultra-high pure as carrier gas. The chromatography oven was programmed with the pressure $16.08 \mathrm{kPa}$ and column flow $1 \mathrm{ml} /$ minute, also the temperature started at $40{ }^{\circ} \mathrm{C}$ and was run until $250^{\circ} \mathrm{C}$ with the rate of $10^{\circ} \mathrm{C}$. minute ${ }^{-1}$ and was detained for 25 minutes. The temperature was increased again from $250-290{ }^{\circ} \mathrm{C}$ with the rate of 10 ${ }^{\circ} \mathrm{C}$.minute ${ }^{-1}$ and then it was held constant for 30 minutes. The compound identification process was done by observing the mass to charge ratio $(\mathrm{m} / \mathrm{z})$ and molecular peak in mass spectrum. The final step was determining carbon number based on the molecule weight which was compared with the literature.

\section{Results and Discussion}

\section{Bacteria isolate}

The number of bacteria isolated varied from which the highest bacterial population of $6 \times 10^{6} \mathrm{CFU}$ $\mathrm{ml}^{-1}$ was obtained at Station A and the lowest of $2 \mathrm{x}$ $10^{2} \mathrm{CFU} \mathrm{ml} \mathrm{I}^{-1}$ at Station $\mathrm{E}$ (Figure 2). Bacterial isolates were cultivated and adapted to environmental conditions containing small volume of oil. The result showed that bacteria were able to grow after cultivation and adaptation (Figure. 3). The highest amount of bacteria population was at Station A with $1.5 \times 10^{7} \mathrm{CFU} \mathrm{ml}^{-1}$. The differences number of population at each station could possibly relate to bacteria ability to adapt with oily media.

The difference number of bacteria population was assumed to be related to the condition of sea water sediment. Station $\mathrm{E}$ was located in the outer part of the harbor, so it was highly affected by the 
ocean, like the tidal current which could disperse the bacteria population to be lower. Otherwise, Station A was located in a more closed area in the harbor, so the possibility of the bacteria getting flushed by the current was low.

The succeeded cultivation process was shown by the increase of population in each station. Bacteria from Station A could grow and adapt well in oily environment shown by its highest population. It is also supported by the high ship activity and it is possible to have the highest oil spill concentration in this station. There was no significant bacteria population increase in Station C and E. Otherwise, bacteria population decreased in Station B and D which indicated that the bacteria could not live well in the oily environment, so it was assumed that the bacteria could not degrade oil. Bacteria from Station A were more potential for biodegradation process because of the positive growth after adaptation process. The identified bacteria are Fundibacter sp., Alcanivorax sp., and Marinobacter sp. The whole bacteria can be found in marine sediments and have the ability to degrade alkane compounds in oil (Macaulay 2013, Liu and Shao 2005, Striebich et al. 2014).

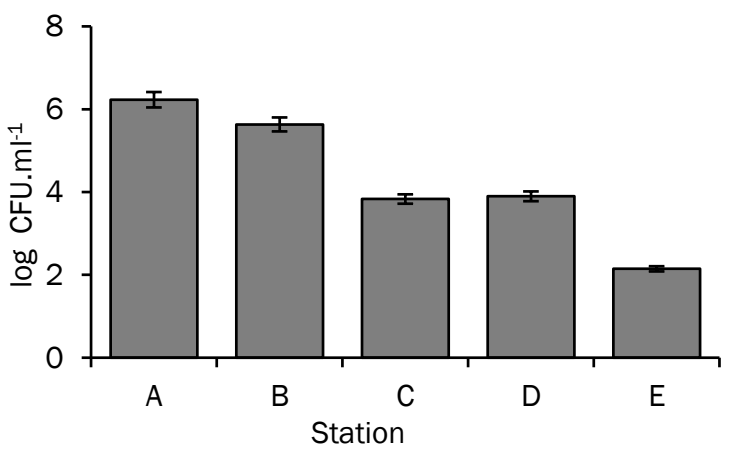

Figure 2. Bacteria population in each station.

\section{Oil biodegradation}

The biodegradation ability of the cultivated and adapted bacteria from Station A was tested using crude oil with concentration 3000 ppm. Crude oil was used with assumption that bacteria could degrade all oil components in the water. The result of biodegradation rate, change of bacteria population, and $\mathrm{pH}$ during the biodegradation process is shown in Figure 4. The bacteria then used in oil-polluted water biodegradation process. Biodegradation

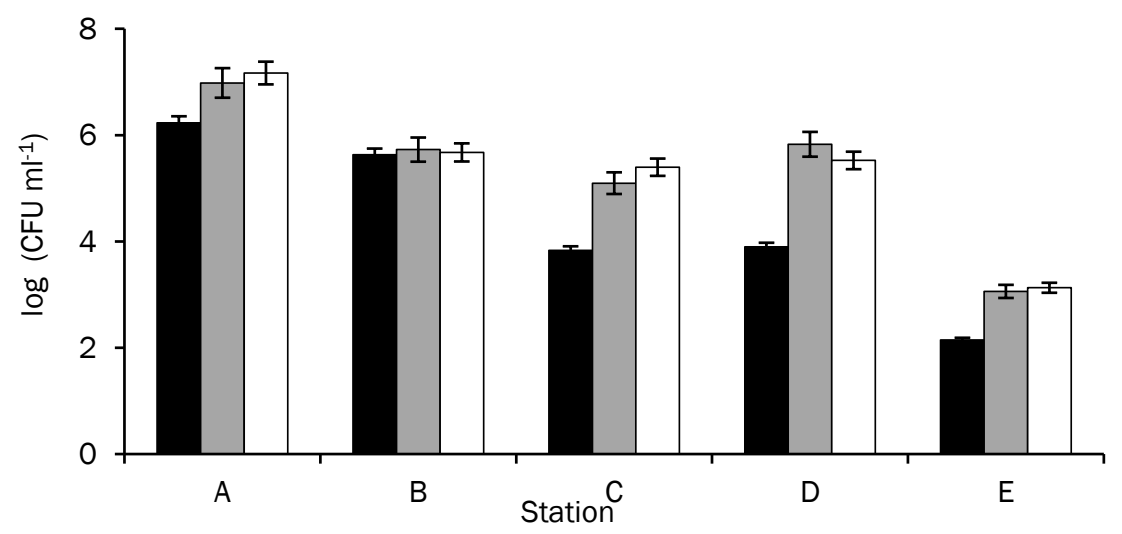

Figure 3. Bacteria population growth after the cultivation and adaptation process Note. $\square$ : cultivation, $\square$ : adaptation I, $\square$ : adaptation II

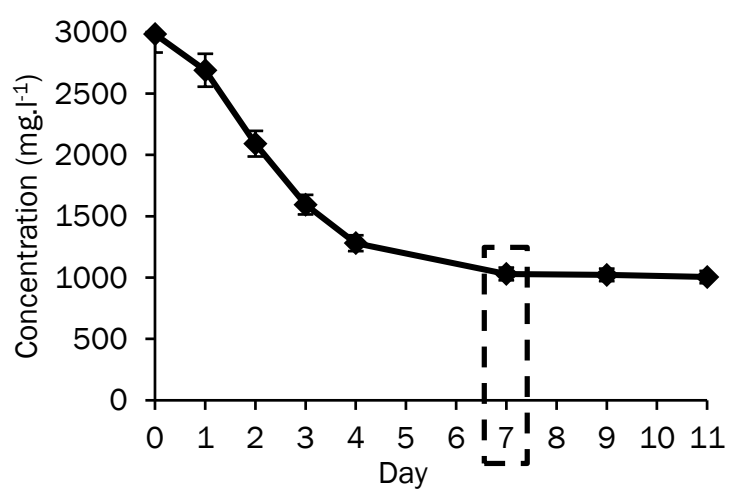

(a)

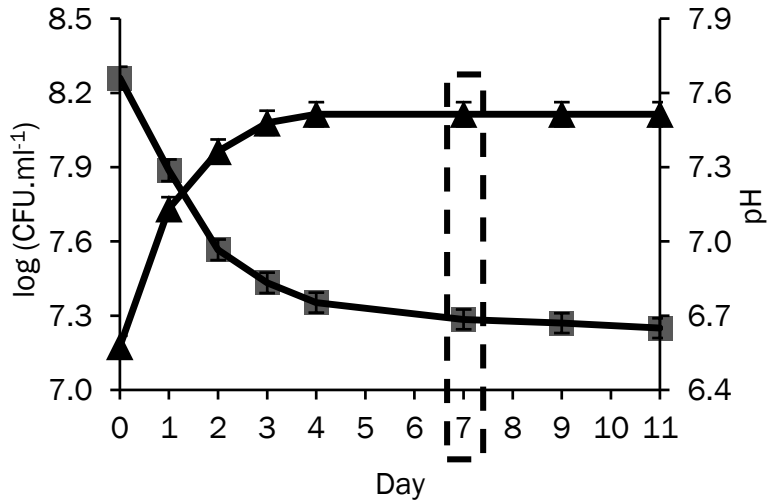

(b)

Figure 4. (a) Bacteria biodegradation rate oil and grease and (b) change of bacteria population $(-\longrightarrow)$ and pH 


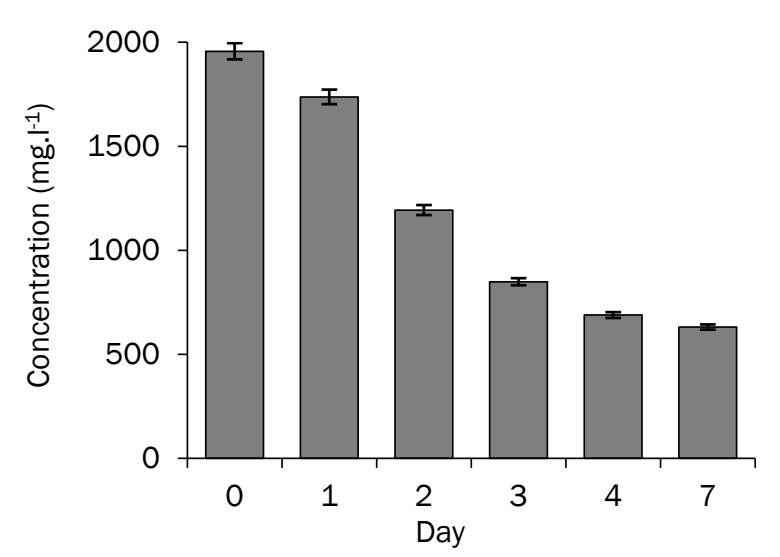

(a)

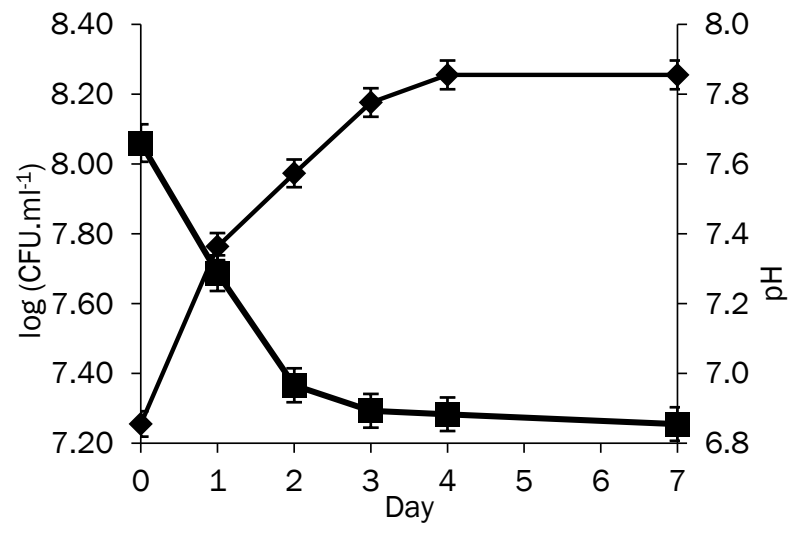

(b)

Figure 5. (a) Oil and grease content, (b) bacteria population $(-\leftarrow$ ) and $\mathrm{pH}(\neg-)$ in Station Angke 1

analysis, bacteria population and $\mathrm{pH}$ measurement in Station Angke 1 was conducted on day-0, 1, 2, 3, 4, and 7. It was because the oil in Station Angke 1 visually had higher oil contents than the other, so the biodegradation rate could be calculated. Otherwise, the other stations were only tested on day-0 and day7. The complete result is shown in Figure 5.

Biodegradation process was successfully done indicated by the decrease of oil and grease content and $\mathrm{pH}$ everyday along with the increase of bacteria population (Figure 5). The biodegradation rate is written by the equation $C_{t}=C_{0} \mathrm{e}^{(-0.1766 t)}$. Oil and grease content measurement was also conducted in other stations with the result is shown in Figure 6.

The chemical analysis of aliphatic fraction by GC-MS revealed oil degradation in carbon number 11 to 27 which shown by chromatogram in Figure 7 and 8. Biodegradation process on contaminated water was also conducted using oil and grease method which referred to ASTM D-4281-95. Oil and grease, $\mathrm{pH}$, and bacteria population analysis in each station were conducted from day-0 until day- 7 . Based on

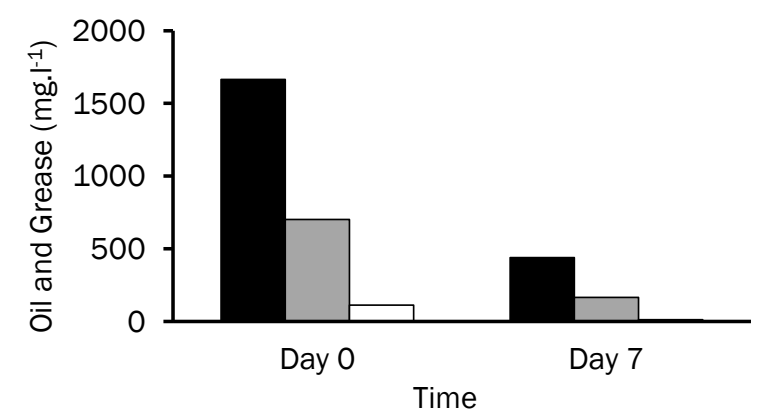

Figure 6. Oil and grease analysis on day 0 and day 7 in different location

Note. $\square$ : Angke 2, $\square$ : Saban 1, $\square$ : Saban 2
Duncan Multiple Range analysis which executes multiple comparison of the mean for each day, bacteria degraded oil effectively on day-7. It can be explained by the insignificant decrease of oil and grease concentration from day-7 until day-11. Biodegradation process went well which was supported by the increasing bacteria population and the decreasing $\mathrm{pH}$ in bacteria solution. The increase of bacteria population means bacteria kept growing and adapting to the environment. The decrease of $\mathrm{pH}$ was caused by the bacteria aerobically breaking the carbon structure in the oil, producing $\mathrm{CO}_{2}$ which reacted with water to form $\mathrm{H}_{2} \mathrm{CO}_{3}$ (Hassanshahian and Capello 2013).

Isolated sea sediment bacteria showed its utilization potential in biodegradation technology alternative, especially natural bacteria from the oilpolluted environment. It was indicated by the bacteria which could degrade oil from different harbors. Previously, bacteria used in biodegradation technology came from the outside of polluted marine environment and was potential in raising alien species invasion, so sea sediment bacteria isolate utilization is potential for safer biodegradation technology in oil-polluted water.

The bacteria could degrade oil in all stations (Figure 6). It is indicated by the proportion of oil and grease concentration on day- 0 and day- 7 in each station. It is also supported by the change of crude oil structure before and after the biodegradation process with the analysis using gas chromatography-mass spectrometry (GC-MS) which is shown in Figure 9. There is a significant decrease of $n-C_{11}-n C_{27}$ compound in both chromatograms. The significant decrease happened to hydrocarbon compound with low molecule weight, for example $n$-heptadecane $(n$ $\left.\mathrm{C}_{17}\right)$ and $n$-octadecane $\left(n-\mathrm{C}_{18}\right)$. It means there was a 


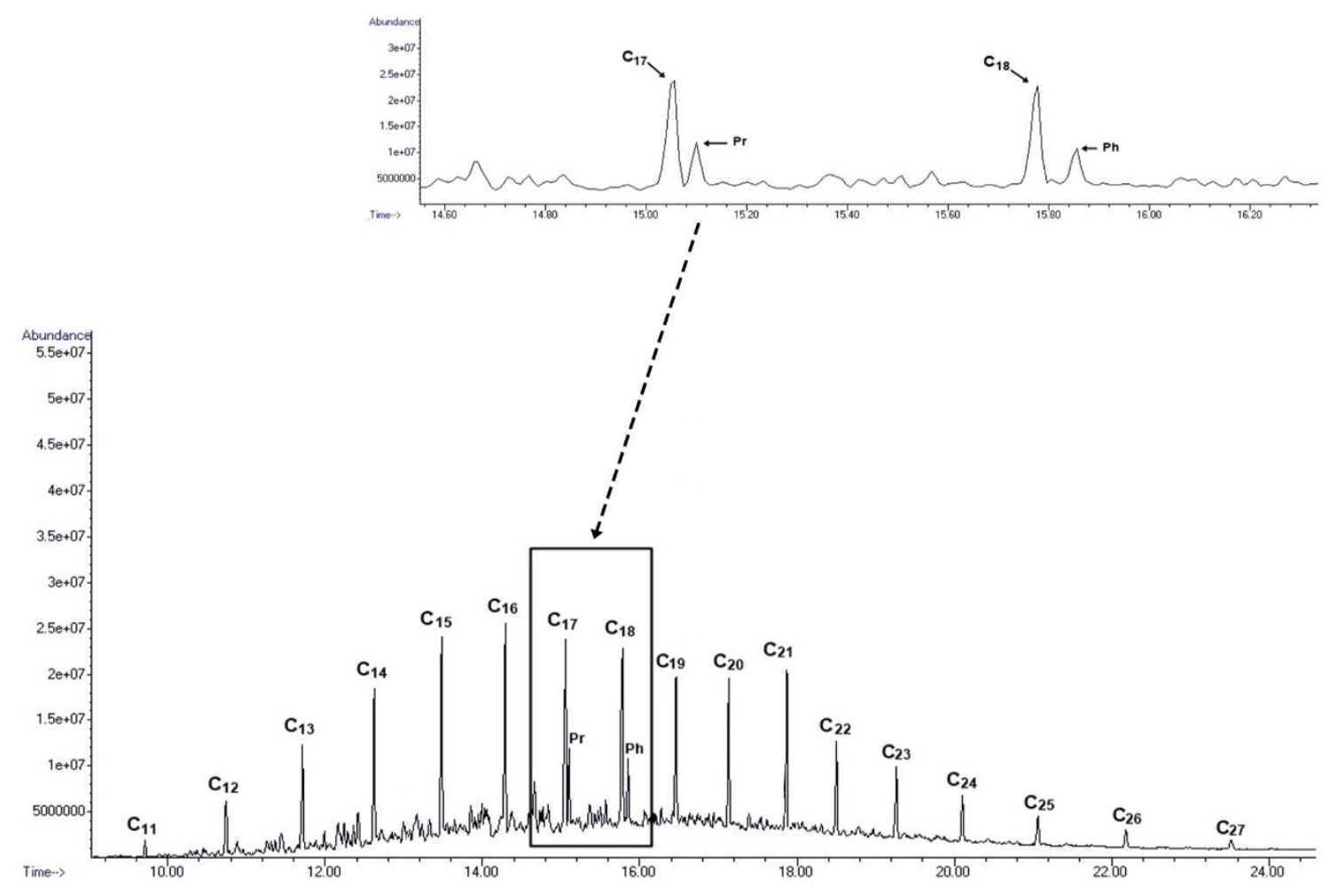

Figure 7. GC-MS analysis result of oil before the biodegradation process

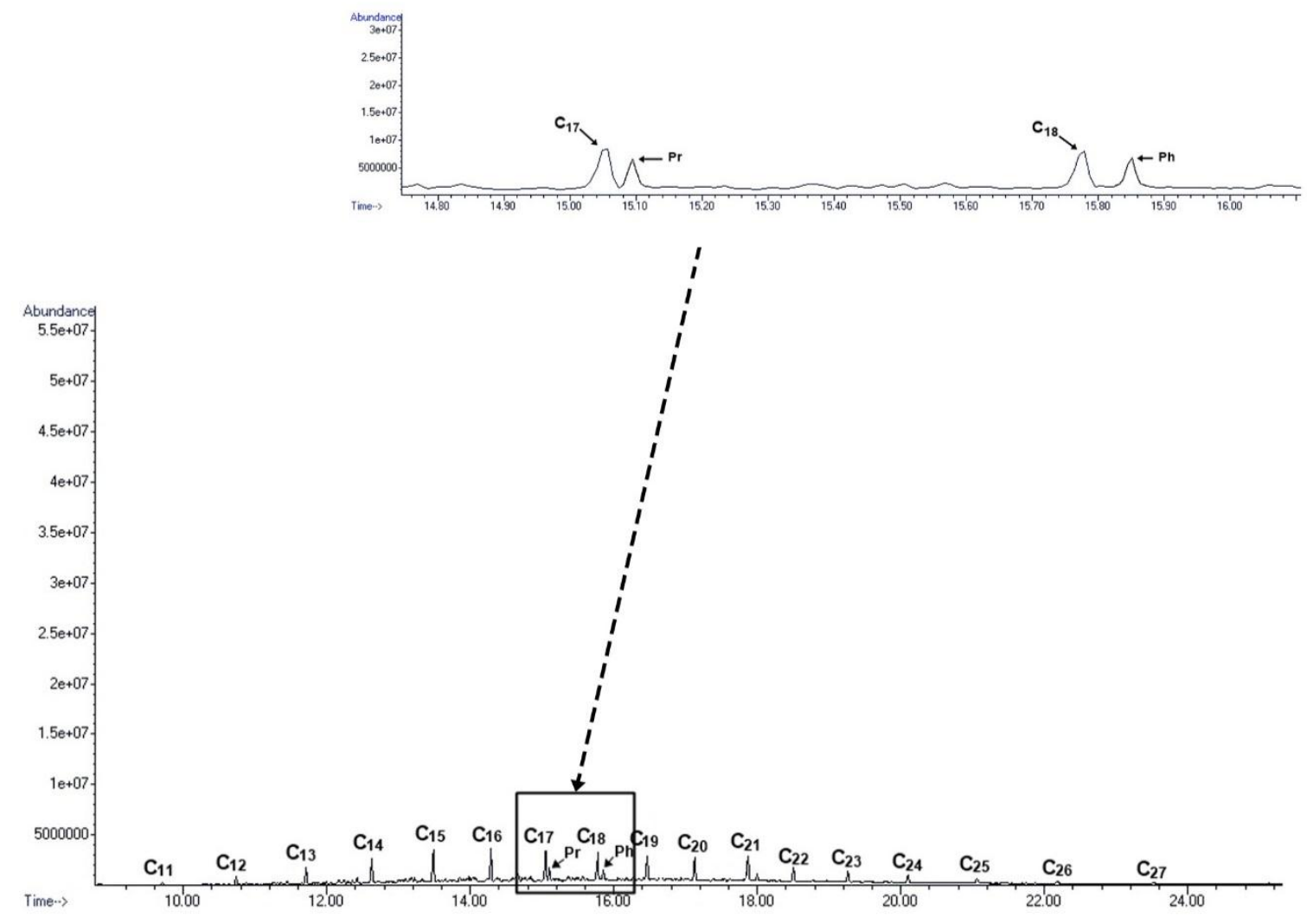

Figure 8. GC-MS analysis result of oil after the biodegradation process 


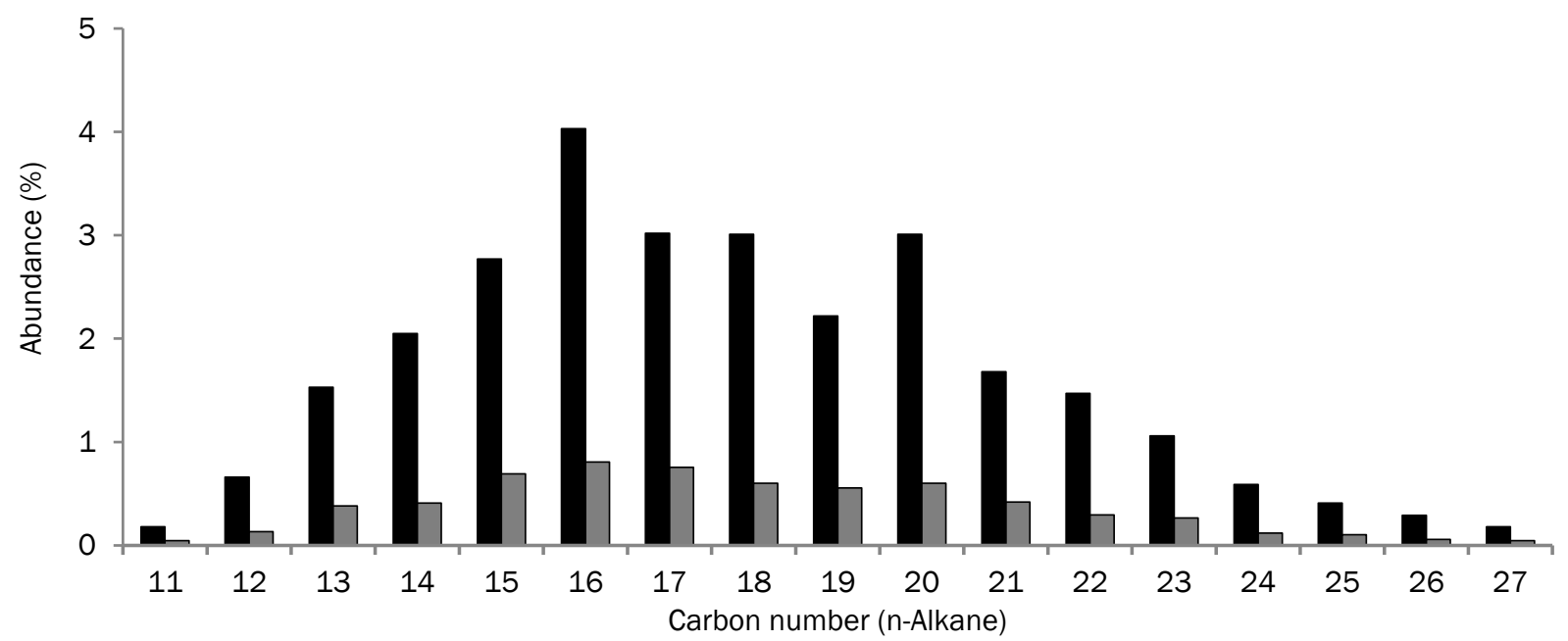

Figure 9. The abundance of each carbon number before and after biodegradation process based on chromatogram Note. $\square$ : before biodegradation, $\square$ : after biodegradation

carbon chain breaking in long chain compound and bacteria is potential for biodegradation process in two different harbors.

\section{Conclusion}

The identified bacteria were Fundibacter sp., Alcanivorax sp., and Marinobacter sp.. Marine sediment bacteria have potency to degrade oil in two different harbors and it is supported by GC-MS analysis which shows the abundance decrease of each compound after biodegradation process.

\section{Acknowledgments}

The authors would like to extend their gratitude and grateful thanks to Directorate General of Higher Education (DIKTI) for financially supporting this work. We also wish to thank to Civitas Academica Department of Marine Science and Technology, Faculty of Fisheries and Marine Science, Bogor Agricultural University. This work also supported by all the staffs of Laboratory of Microbiology Center for Research and Technology Development of Oil and Gas Ministry of Energy and Mineral Resources Jakarta, Integrated Laboratory Faculty of Fisheries and Marine Science Bogor Agricultural University, Laboratory of GC-MS Forensic Center Police Criminal Investigation, Laboratory of Microbiology Faculty of Medical University of Indonesia.

\section{References}

[APHA] American Public Health Association. 2012. Total Plate Count. Standard Methods for the Examination of Water and Wastewater 22nd ed.
[ASTM] American Society and Testing Materials. 2010. Standard Test Method for Oil and Grease (Fluorocarbon Extractable Substances) by Gravimetric Determination. ASTM Water and Environmental Technology Water II 11(2):471476.

Ahmed, A.W., Alzubaidi, F.S. \& Hamza, S.J.. 2014. Biodegradation of crude oil in contaminated water by local isolates of Enterobacter cloacae. J. Sci. 55(3): 1025-1033.

Al-Wasify, R.S. \& Hamed, S.R. 2014. Bacterial Biodegradation of Crude Oil Using Local Isolates. J Microbiol. 2010:1-8. doi:10.1155/2014/863 272.

Atlas, R.M.. 2010. Handbook of Microbiological Media 4th ed. Boca Raton (US): CRC Press. $p$ 1403.

Darmayati, Y. 2009. Development of oil bioremediation research on marine environment in Indonesia. Coast Dev 12(3): 105-110.

Darmayati, Y., Sanusi, H.S., Prartono, T., Santosa, D.W. \& Nuchsin, R.. 2015. The effect of biostimulation and biostimulationbioaugmentation on biodegradation of oilpollution on sandy beaches using mesocosms. Int. J. Mar. Sci. 5(27):1-11. doi: 10.5376/ijms. 2015.05.0027

Hassanshahian, M. \& Cappello, S., 2013. Crude oil biodegradation in Marine Environments. Biodeg Eng Tech: 101-136. doi: 10.5772/55554.

Liu, C. and Shao, Z., 2005. Alcanivorax dieselolei sp. nov., a novel alkane-degrading bacterium isolated from sea water and deep-sea sediment. 
Int. J. Systematic Evolutionary Microbiol., 55(3):1181-1186.

Macaulay, B.M.. 2013. Understanding the behaviour of oil-degrading micro-organisms to enchance the microbial remediation of spilled petroleum. Appl. Eco.l Env. Res. 13(1):247-262. doi: 10.15666/aeer/1301_247262.

Ni'matuzahroh, Yahya. A., \&, Tandjung. M. 2006. A comparative study of Pseudomonas aeruginosa IA7d biosurfactant and Tween-80 synthetic surfactant in the solar biodegradation by microbes from Tanjung Perak Surabaya waters. Hayati 12(2006):13-18.

Nugroho, A. 2006. Biodegradation of oil sludge in microcosm scale: simple simulation as a preliminary assessment land treatment bioremediation. Makara J Tek. 10(2):82-89.

Okoro, C.C.. 2010. Enchanced Bioremediation of Hydrocarbon Contaminated Mangrove Swamp in the Nigerian Oil Rich Niger Delta using Seawater Microbial Inocula amended with Crude Biosurfactants and Micronutrients. Nat. Sci. 8(8):195-206.

Prartono. T. \& Wolff. G.A. 1998. Organic geochemistry of lacustrine sediments: a record of the changing trophic status of Rostherne Mere, U.K. Org. Geochem. 28(11):729-747.

Rampen, S.W., Sinninghe. D.J.S., Schouten. S. \& Middelburg. J.J.. 2012. Characterization of the deep-sea microbial community and investigation of their carbon sources using lipid biomarkers. American Geophysical Union, Fall Meeting 2012: Oceanogr. Biol. Chem. 84: 204-216. doi: 10.1016/j.gca.2012.01.024
Razika, B., Abbes, B., Messaoud, C. \& Soufi, K. 2010. Phenol and benzoic acid degradation by Pseudomonas aeruginosa. J Water Resource Prot 2:788-791. doi: 10.4236/jwarp.2010. 29092.

Striebich, R., Smart, C.E., Gunasekera, T.S., Mueller, S.S., Strobel, E.M., McNichols, B.W. \& Ruiz, O.N. 2014. Characterization of the F-76 diesel and Jet-A aviation fuel hydrocarbon degradation profiles of Pseudomonas aeruginosa and Marinobacter hydrocarbonoclasticus. Int. Biodeterior Biodegradation 93: 33-43.

Thapa, B., Ajay K.K.C., \& Ghimire A.. 2012. A Review on Bioremediation of Pertoleum Hydrocarbon Contaminant in Soil. J. Sci. Eng. Tech. 8(1):164170.

[US EPA] United States Environmental Protection Agency. 2014. The Fate of Spilled Oil. Understanding Oil Spills and Oil Spill Response:4-8.

Wragg, P., Randall, L. and Whatmore, A.M., 2014. Comparison of Biolog GEN III MicroStation semiautomated bacterial identification system with matrix-assisted laser desorption ionization-time of flight mass spectrometry and 165 ribosomal RNA gene sequencing for the identification of bacteria of veterinary interest. J. Microbiol. Methods, 105:16-21.

Zheng, Y., Liu, D., Xu, H., Zhong, Y., Yuan, Y., Xiong, L. and Li, W., 2009. Biodegradation of $p$ nitrophenol by Pseudomonas aeruginosa HSD38 and analysis of metabolites with HPLCESI/MS. Int. Biodeterioration Biodegradation, 63(8):1125-1129. 